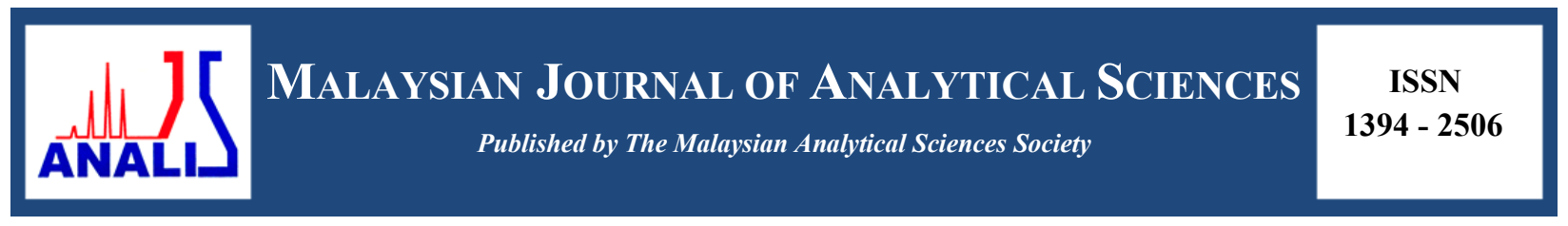

\title{
SYNTHESIS OF BENZOTHIAZOLE DERIVATIVES USING ULTRASONIC PROBE IRRADIATION
}

\author{
(Sintesis Terbitan Benzothiazola Dengan Menggunakan Prob Penyinaran Ultrasonik) \\ Su-Yin Kan ${ }^{1}$, Wei Sern Yiong ${ }^{2}$, Fu Siong Julius Yong ${ }^{3}$, Poh Wai Chia ${ }^{2,3 *}$ \\ ${ }^{1}$ Faculty of Health Sciences, \\ Universiti Sultan Zainal Abidin, 21030 Kuala Nerus, Malaysia \\ ${ }^{2}$ School of Marine and Environmental Science \\ ${ }^{3}$ Institute Marine Biotechnology \\ Universiti Malaysia Terengganu, 21030 Kuala Nerus, Malaysia \\ *Corresponding author: pohwai@umt.edu.my
}

Received: 14 June 2017; Accepted: 17 September 2017

\begin{abstract}
Benzothiazoles are an important class of pharmaceutical drug with various therapeutic activities. In this work, an efficient and eco-friendly method of synthesizing of benzothiazole derivatives via ultrasonic probe irradiation was described here. Through the improved protocol, the benzothiazole derivatives were prepared with various benzaldehyde and 2-aminothiophenol. The yields were found to be in moderate to good yields, ranging from $65-83 \%$. Among the advantages of this procedure as compared to the conventional methods of synthesizing benzothiazoles include simplicity in the procedure, solvent-, catalyst- free reaction and the improved protocol afforded compounds (4a-4i) within 20 minutes at room temperature. The current improved protocol could be extended for the synthesis of other bioactive heterocyclic compounds in future work.
\end{abstract}

Keywords: benzothiazole, ultrasound, solvent-free, catalyst-free.

\begin{abstract}
Abstrak
Benzotiazola adalah kelas ubat farmaseutikal yang penting dengan pelbagai aktiviti terapeutik. Dalam kajian ini, satu kaedah yang efisien dan mesra alam bagi sintesis terbitan benzotiazola dengan menggunakan prob penyinaran ultrasonik dibincangkan. Melalui kaedah yang ditambahbaik, terbitan benzotiazola dapat disediakan melalui pelbagai benzaldehid dan 2-aminatiofenol. Peratusan hasil produk didapati dari sederhana hingga baik, iaitu antara julat $65-83 \%$. Kelebihan protokol ini berbanding dengan kaedah - kaedah konvensional bagi sintesis terbitan benzatiazola, termasuk prosedur yang mudah, tanpa penggunaan pelarut, tanpa pemangkin dan protokol yang ditambahbaik menghasilkan sebatian (4a-4i) dalam masa 20 minit pada suhu bilik. Kaedah yang ditambahbaik kini boleh diperluaskan untuk sintesis sebatian heterosiklik bioaktif lain dalam kajian masa hadapan.
\end{abstract}

Kata kunci: benzotiazola, prob penyinaran ultrasonik, tanpa pengunaan pelarut, tanpa penggunaan pemangkin

\section{Introduction}

Benzothiazoles belong to an important class of pharmaceutical drug that possesses many desirable biological activities, such as antibacterial [1], anticonvulsant [2], anticancer [3], antifungal [4], antimitotic [5], and antitumor [6] properties. Examples of pharmaceutical drugs that contain the benzothiazole moiety include frentizole 1 (an immunosuppressive agent) [7]; ethoxyzolamide 2 (a carbonic anhydrase inhibitor) [8] and riluzole 3 (a registered drug used to treat patients with amyotrophic lateral sclerosis) [9] (Figure 1). In the past, various synthetic pathways for the synthesis of benzothiazole and its derivatives have been reported, including the utilization of microwave 
irradiation [10], reusable metal-based catalysis [11], utilization of rare earth based nanocatalyst coupled with ultrasound irradiation [12] and utilization of water in combination with ionic liquid system [13]. Although there is an effort to improve on the efficiency of benzothiazole synthesis, most of these reactions suffer from drawbacks such as less eco-friendly, long reaction time and use of additives in synthesizing benzothiazole derivatives [14]. To that end, method development in the search for a simple and efficient synthetic route for synthesizing bioactive compounds has always been one of the major challenges in organic synthesis research works.

Over the years, the application of ultrasound in chemical synthesis has been an attractive and efficient method, especially to overcome the low reaction rate in chemical synthesis [15]. For instance, a solventless ultrasoundmediated reaction for the synthesis of thiazolo[3,2-a]pyrimidine derivatives have been successfully carried out with good yields [16]. Besides, a shorter reaction time was reported on the production of 2,4,5-trisubstituted imidazoles using Selectfluor ${ }^{\mathrm{TM}}$ as catalyst with the employment of ultrasound technique [17]. A green synthesis of sulfonamides with the aid of a natural, efficient and reusable Natrolite nanozeolite catalyst under ultrasound irradiation was also disclosed recently [18]. The utilization of ultrasound in organic reactions can overcome poor mass transfer and interaction between reactants. Through this technique, tremendous amount of energies for chemical activation was supplied by the means of cavitation through bubbles formation, expansion and rupture, which led to a better interaction between reactants [19]. To date, a vast number of useful organic compounds have been generated by using the ultrasound method [20].<smiles>COc1ccc2nc(NC(=O)CNc3ccccc3)sc2c1</smiles>

1

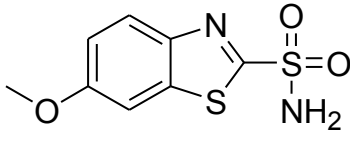

2

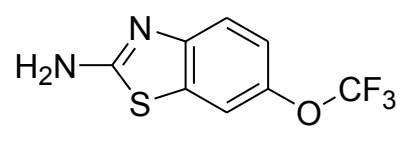

3

Figure 1. The benzothiazole drugs used for the treatment of various diseases. $1=$ frentizole. $2=$ ethoxyzolamide and 3 = riluzole

In our continuous efforts to search for an efficient method for synthesizing bioactive heterocyclic compounds, herein, we reported on the synthesis of benzothiazole and their derivatives under ultrasound probe irradiation by using 2-aminothiophenol and benzaldehydes as starting materials (Scheme 1).

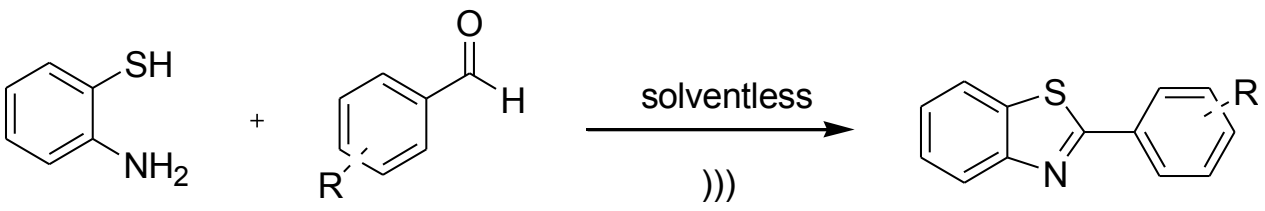

Scheme 1. Synthetic pathway towards the formation of benzothiazoles

\section{Materials and instrumentation}

\section{Materials and Methods}

All the chemicals and solvents used in this study were of technical grade and were supplied by Merck, Acros Organics and $\mathrm{HmbG}{ }^{\circledR}$ chemicals and were used without further purification. These chemicals include 
benzaldehyde, 2-chlorobenzaldehyde, 3-chlorobenzldehyde, 4-chlorobenzaldehyde, 2-fluorobenzaldehyde, 4fluorobenzldehyde, 4-bromobenzaldehyde, 4-isoporpylbenzaldehyde, 4-methoxybenzaldehyde, ethyl acetate, nhexane and silica gel $60(0.063-0.200 \mathrm{~mm})$. The FT-IR spectra were recorded using Perkin Elmer 100 FT-IR spectrometer, in spectral range of 4000-400 cm-1. ${ }^{1} \mathrm{H}$ and ${ }^{13} \mathrm{C}-\mathrm{NMR}$ spectra were recorded on Bruker Avance III 400 spectrometer, with deuterated chloroform as solvent at room temperature at $400 \mathrm{MHz}$. GC-MS analyses were carried out using Shimadzu QP2010SE. Normal phase GC-MS analysis used a Supelco fused silica capillary column $(30 \mathrm{~m} \times 0.25 \mathrm{~mm}$ i.d., $0.25 \mathrm{~mm}$ film thickness). The aliquot samples were injected directly onto GCMS with methanol as solvent. The oven was held at $50{ }^{\circ} \mathrm{C}$ for $5 \mathrm{~min}$, subsequently heated at a gradient of $20{ }^{\circ} \mathrm{C} / \mathrm{min}$ to 150 ${ }^{\circ} \mathrm{C}, 280{ }^{\circ} \mathrm{C}$ injector temperature; $100: 1$ split ratio and $1.0 \mathrm{~mL} / \mathrm{min}$ flow.

\section{Synthesis procedure for benzothiazole derivatives $4 \mathrm{a}-4 \mathrm{~h}$.}

2-aminothiophenol $(3.00 \mathrm{mmol})$ was added into benzaldehyde derivatives $(3.00 \mathrm{mmol})$ and the mixture was irradiated under ultrasonic probe for $20 \mathrm{~min}$. The crude product was then purified over silica gel column chromatography (Hexane: Ethyl acetate $=9.5: 0.5, \mathrm{v} / \mathrm{v}$ ) to afford the title compounds $\mathbf{4 a}-\mathbf{4 h}$ except for compound $\mathbf{4 i}$ which was purified with a different solvent system (Hexane: Ethyl acetate $=8.5: 1.5, \mathrm{v} / \mathrm{v}$ ) over silica gel column chromatography.

\section{Physical and spectral data}

\section{Results and Discussion}

The spectroscopic data of the synthesized compounds $\mathbf{4 a - 4 i}$ is as follows:

(4a) 2-phenylbenzothiazole

M.p: $112.0{ }^{\circ} \mathrm{C}$; IR $\left(\mathrm{cm}^{-1}\right)$ : 3064.99, 1589.52-1433.53; ${ }^{1} \mathrm{H}-\mathrm{NMR}(\mathrm{ppm}): 7.42$ (t, 1H), 7.51-7.53 (m, 4H), 7.91-7.93 $(\mathrm{d}, J=8.0 \mathrm{~Hz}, 1 \mathrm{H}), 8.14(\mathrm{~m}, 3 \mathrm{H}) ;{ }^{13} \mathrm{C}-\mathrm{NMR}(\mathrm{ppm}): 122.09,124.35,125.48,126.66,127.60,128.07,130.19$, 133.75, 136.06, 152.54, 167.30. GC-MS: m/z $211[\mathrm{M}]^{+}$.

(4b) 2-(2-chlorophenyl) benzothiazole

M.p: $84.0{ }^{\circ} \mathrm{C}$; IR $\left(\mathrm{cm}^{-1}\right)$ : 3067.21, 1586.06-1441.40, 750.09; ${ }^{1} \mathrm{H}-\mathrm{NMR}(\mathrm{ppm}):$ 7.43-7.36 (m, 3H), 7.53-7.51 (m, 2H), $8.12(\mathrm{~d}, J=8.1 \mathrm{~Hz}, 1 \mathrm{H}), 8.21-8.23(\mathrm{~m}, 1 \mathrm{H}) ;{ }^{13} \mathrm{C}-\mathrm{NMR}(\mathrm{ppm}): 121.3,123.3,125.4,126,3,127.2,130.6,131.5$, $132.4,132.5,136.3,152.4 .4,164.2$ GC-MS: $\mathrm{m} / \mathrm{z} 245[\mathrm{M}]^{+}$.

(4c) 2-(3-chlorophenyl) benzothiazole

M.p: $97.0^{\circ} \mathrm{C}$; IR $\left(\mathrm{cm}^{-1}\right): 3075.40,1580.54-1430.01,751.87 ;{ }^{1} \mathrm{H}-\mathrm{NMR}(\mathrm{ppm}): 7.51-7.34(\mathrm{~d}, J=8.0 \mathrm{~Hz}, 2 \mathrm{H}), 8.00(\mathrm{~d}$, $J=8.5 \mathrm{~Hz}, 2 \mathrm{H}) 8.05(\mathrm{~d}, J=8.1 \mathrm{~Hz}, 1 \mathrm{H}) ;{ }^{13} \mathrm{C}-\mathrm{NMR}(\mathrm{ppm}): 121.4,123.4,125.3,126,4,128.6,129.0,132.0,135.1$, 137.1, 154.3, 166.4. GC-MS: m/z $245[\mathrm{M}]^{+}$.

(4d) 2-(4-chlorophenyl) benzothiazole

M.p: $117.0{ }^{\circ} \mathrm{C}$; IR $\left(\mathrm{cm}^{-1}\right): 3065.40,1543.21-1421.34,752.34 ;{ }^{1} \mathrm{H}-\mathrm{NMR}(\mathrm{ppm}): 7.21-7.15(\mathrm{~m}, 2 \mathrm{H}), 7.39$ (t, $J=7.5$ $\mathrm{Hz}, 1 \mathrm{H}), 7.51(\mathrm{t}, J=7.9 \mathrm{~Hz}, 1 \mathrm{H}), 7.86(\mathrm{~d}, J=7.9 \mathrm{~Hz}, 1 \mathrm{H}), 8.04-8.06(\mathrm{~m}, 3 \mathrm{H}) ;{ }^{13} \mathrm{C}-\mathrm{NMR}(\mathrm{ppm}): 16.3,121.4,123.3$, $125.4,126.5,129.2,130.2,135.2,135.4,154.3,163.5,166.0$. GC-MS: m/z $245[\mathrm{M}]^{+}$.

(4e) 2-(2-fluorophenyl) benzothiazole

M.p:67.0 ${ }^{\circ} \mathrm{C}$; IR $\left(\mathrm{cm}^{-1}\right)$ : 3055.60, 1590.54-1434.68, 756.79; ${ }^{1} \mathrm{H}-\mathrm{NMR}(\mathrm{ppm}): 7.21(\mathrm{~d}, J=7.5 \mathrm{~Hz}, 1 \mathrm{H}), 7.31(\mathrm{~d}, J=$ $7.5 \mathrm{~Hz}, 1 \mathrm{H}), 7.31(\mathrm{t}, J=7.8 \mathrm{~Hz}, 2 \mathrm{H}), 7.45(\mathrm{~m}, 3 \mathrm{H}), 7.93(\mathrm{~d}, J=8.1 \mathrm{~Hz}, 1 \mathrm{H}), 8.11(\mathrm{~d}, J=8.1 \mathrm{~Hz}, 1 \mathrm{H}), 8.40,(\mathrm{t}, J=7.5$ $\mathrm{Hz}, 1 \mathrm{H}) ;{ }^{13} \mathrm{C}-\mathrm{NMR}(\mathrm{ppm}): 116.3,121.5,123.4,124.5,124.6,125.2,126.2,129.4,132.0,135.6,152.4,160.0$, 162.1. GC-MS: m/z $229[\mathrm{M}]^{+}$.

(4f) 2-(4-fluorophenyl) benzothiazole

M.p:100.0 ${ }^{\circ} \mathrm{C}$; IR $\left(\mathrm{cm}^{-1}\right): 3049.20,1591.54-1484.22,829.28 ;{ }^{1} \mathrm{H}-\mathrm{NMR}$ (ppm): 7.21 (d, $\left.J=7.5 \mathrm{~Hz}, 1 \mathrm{H}\right), 7.31$ (d, $J=$ $7.5 \mathrm{~Hz}, 1 \mathrm{H}), 7.31(\mathrm{t}, J=7.8 \mathrm{~Hz}, 2 \mathrm{H}), 7.45(\mathrm{~m}, 3 \mathrm{H}), 7.93(\mathrm{~d}, J=8.1 \mathrm{~Hz}, 1 \mathrm{H}), 8.11(\mathrm{~d}, J=8.1 \mathrm{~Hz}, 1 \mathrm{H}), 8.40,(\mathrm{t}, J=7.5$ $\mathrm{Hz}, 1 \mathrm{H}) ;{ }^{13} \mathrm{C}$ - NMR (ppm): 116.3, 121.5, 123.4, 124.5, 124.6, 125.2, 126.2, 129.4, 132.0, 135.6, 152.4, 160.0, 162.1. GC-MS: m/z $229[\mathrm{M}]^{+}$. 
(4g) 2-(4-bromophenyl) benzothiazole M.p:131.0 ${ }^{\circ} \mathrm{C}$; IR $\left(\mathrm{cm}^{-1}\right): 3005.60,1604-1408.68,689.79 ;{ }^{1} \mathrm{H}-\mathrm{NMR}(\mathrm{ppm}): 7.38(\mathrm{t}, J=7.6 \mathrm{~Hz}, 1 \mathrm{H}), 7.51(\mathrm{t}, J=7.5$ $\mathrm{Hz}, 1 \mathrm{H}), 7.66-7.61,(\mathrm{~m}, 2 \mathrm{H}), 7.87(\mathrm{~d}, J=7.7 \mathrm{~Hz}, 1 \mathrm{H}), 7.94(\mathrm{~d}, J=8.7 \mathrm{~Hz}, 2 \mathrm{H}), 8.05(\mathrm{~d}, J=8.1 \mathrm{~Hz}, 1 \mathrm{H}) ;{ }^{13} \mathrm{C}-\mathrm{NMR}$ (ppm): 121.4, 123.3, 125.2, 125,3, 126.4, 128.8, 132.1, 132.4, 135.1, 154.2, 166.5. GC-MS: m/z 288 [M] .

(4h) 2-(4-isopropylphenyl) benzothiazole

M.p: $119.0{ }^{\circ} \mathrm{C}$; IR $\left(\mathrm{cm}^{-1}\right)$ : 2956, 2981, 1602.01-1484.00, 967.89; ${ }^{1} \mathrm{H}-\mathrm{NMR}(\mathrm{ppm}): 1.25$ (d, $\left.J=7.3 \mathrm{~Hz}, 6 \mathrm{H}\right), 2.86(\mathrm{~m}$, 1H), 7.42-7.51, (m, 2H), 7.60-7.63 (m, 2H), 7.74-7.83 (m, 2H), 8.04-8.12 (m, 2H); ${ }^{13} \mathrm{C}-\mathrm{NMR}(\mathrm{ppm}): 23.5,34.1$, $122.2,122.5,125.2,125.4,127.3,128.2,140.1,149.0,149.2,153.1,169.4$. GC-MS: $\mathrm{m} / \mathrm{z} 253[\mathrm{M}]^{+}$.

(4i) 2-(4-methoxyphenyl) benzothiazole

M.p: $289.0{ }^{\circ} \mathrm{C}$; IR $\left(\mathrm{cm}^{-1}\right)$ : $3382.00,1613-1431.00,811.00 ;{ }^{1} \mathrm{H}-\mathrm{NMR}(\mathrm{ppm})$ : 7.87-8.06 (m, 4H), 7.51 (t, $J=7.3 \mathrm{~Hz}$, $1 \mathrm{H}), 7.38,(\mathrm{t}, J=7.4 \mathrm{~Hz}, 1 \mathrm{H}), 7.07(\mathrm{~d}, J=8.2 \mathrm{~Hz}, 2 \mathrm{H}), 3.8(\mathrm{~s}, 3 \mathrm{H}) ;{ }^{13} \mathrm{C}-\mathrm{NMR}(\mathrm{ppm}): 55.3,114.6,122.2,122.3$, $125.1,125.4,126.3,128.7,134.1,153.5,161.6,167.0$. GC-MS: m/z $124.0[\mathrm{M}]^{+}$.

For the preliminary reaction, the optimized condition was determined by using a model reaction where 2aminothiophenol and benzaldehyde were reacted in the presence of ultrasound probe irradiation to yield the corresponding product $4 \mathbf{a}$. Based on the preliminary study, the yield of $4 \mathbf{a}$ has reached a plateau at $51 \mathrm{~W}$ power and the reaction yield was recorded at $83 \%$ after $20 \mathrm{~min}$ of sonication (Table 1). The synthesis of other benzothiazole derivatives was repeated by using this optimized condition and the improved protocol was also employed for other comparative study.

The effectiveness of the improved protocol was also evaluated by comparing it with ultrasonic bath method and conventional heating method, using the synthesis of $\mathbf{4 a}$ as the model reaction (Table 2). Under the ultrasonic bath method, there was no reaction occurred for the first $20 \mathrm{~min}$ at constant room temperature. While, after the reaction proceeded for $30 \mathrm{~min}$, only less than $10 \%$ yield of $\mathbf{4 a}$ was recorded. The main reason for the low yield may due to inadequate heat energy produced in the reaction to agitate the reaction medium and thus required longer reaction time to produce compound 4a. In contrast, the synthesis of $\mathbf{4 a}$ under conventional heating method has recorded a 60 $\%$ yield when the reaction was heated under reflux with methanol as solvent for $6 \mathrm{~h}$. Hence, it is evident that the ultrasound probe irradiation method under solvent- and catalyst-free condition gave the best yield as compared to the ultrasonic bath and conventional heating methods.

Table 1. The ultrasound yields of $\mathbf{4 a}$ under solvent- and catalyst-free conditions

\begin{tabular}{lccc}
\hline Entry & $\begin{array}{c}\text { Power } \\
(\mathbf{W})\end{array}$ & $\begin{array}{c}\text { Time } \\
(\mathbf{m i n})\end{array}$ & $\begin{array}{c}\text { Isolated } \\
\text { Yield (\%) }\end{array}$ \\
\hline 1 & 46 & 5 & 60 \\
2 & 48 & 10 & 70 \\
3 & 50 & 15 & 73 \\
4 & 51 & 20 & 83 \\
5 & 51 & 25 & 83 \\
6 & 51 & 30 & 83 \\
7 & 53 & 25 & 83 \\
\hline
\end{tabular}


Table 2. The yield of $\mathbf{4 a}$ under ultrasonic bath irradiation and silent condition

\begin{tabular}{|c|c|c|}
\hline \multirow{2}{*}{ Time (min) } & \multicolumn{2}{|c|}{ Isolated Yield (\%) } \\
\hline & Sonication & Conventional \\
\hline 10 & 0 & - \\
\hline 20 & 0 & - \\
\hline 30 & 7 & - \\
\hline 120 & - & 20 \\
\hline 360 & - & 60 \\
\hline
\end{tabular}

Next, we attempt to widen the scope of our study by synthesizing different substituted benzothiazole derivatives by using several electron-donating and electron-withdrawing benzaldehydes under solvent- and catalysts-free ultrasound probe irradiation. As indicated in Table 3, the condensation of different benzaldehydes and 2aminothiophenol proceeded smoothly under the improved protocol and afforded the title compounds (4a-4i) in moderate to good yields $(65-83 \%)$ within 20 minutes at room temperature. The electronic effect and the position of the substitution on the benzaldehydes were found to have negligible effect in the reactivity of the synthesis of benzothiazole derivatives (Table 3, $\mathbf{4 b}-\mathbf{4 g}$ vs. $\mathbf{4 h}-\mathbf{4 i}$ ). The result of this study was congruent with a previous study on the synthesis of the benzothiazole derivatives using ammonium nickel sulfate in the presence of water assisted by ultrasound irradiation method [21]. The major advantages of this technique include short reaction time, solvent- and catalyst-free reaction condition and the final products were obtained in moderate to good yields in comparison to previous method $[11,12,13]$.

Table 3. Isolated yields obtained for compounds $\mathbf{4 a - 4 i}$

\begin{tabular}{lllccl}
\hline Entry & Product No. & $\mathbf{R}$ & $\begin{array}{c}\text { Isolated Yield } \\
(\%)\end{array}$ & $\begin{array}{c}\text { M. P }\left({ }^{\mathbf{0}} \mathbf{C}\right) \\
\text { Observed }\end{array}$ & $\begin{array}{l}\text { M. P }\left({ }^{\mathbf{0}} \mathbf{C}\right) \\
\text { Reported }\end{array}$ \\
\hline 1 & $4 \mathrm{a}$ & $\mathrm{H}$ & 83 & 112 & $112-114[22]$ \\
2 & $4 \mathrm{~b}$ & $2-\mathrm{Cl}$ & 70 & 84 & $84-85[22]$ \\
3 & $4 \mathrm{c}$ & $3-\mathrm{Cl}$ & 65 & 97 & $97-98[22]$ \\
4 & $4 \mathrm{~d}$ & $4-\mathrm{Cl}$ & 65 & 117 & $115-117[22]$ \\
5 & $4 \mathrm{e}$ & $2-\mathrm{F}$ & 69 & 67 & $67-68[22]$ \\
6 & $4 \mathrm{f}$ & $4-\mathrm{F}$ & 66 & 100 & $98-100[22]$ \\
7 & $4 \mathrm{~g}$ & $4-\mathrm{Br}$ & 65 & 131 & $129-131[22]$ \\
8 & $4 \mathrm{~h}$ & $4-\mathrm{CH}\left(\mathrm{CH}_{3}\right)_{2}$ & 65 & 119 & $119-120[23]$ \\
9 & $4 \mathrm{i}$ & $4-\mathrm{OCH}_{3}$ & 65 & 124 & $123-125[22]$ \\
\hline
\end{tabular}

A plausible mechanism for the formation of benzothiazole under the ultrasound probe irradiation is depicted in Scheme 2. Under the ultrasound probe irradiation, the nucleophilic attack of 2-aminothiophenol on the carbonyl of benzaldehydes led to the formation of intermediate (I). Subsequently, cyclization reaction occurred to yield the intermediate (II). The air oxidation of intermediate (II) furnish the end-products, which were the benzothiazole derivatives. 


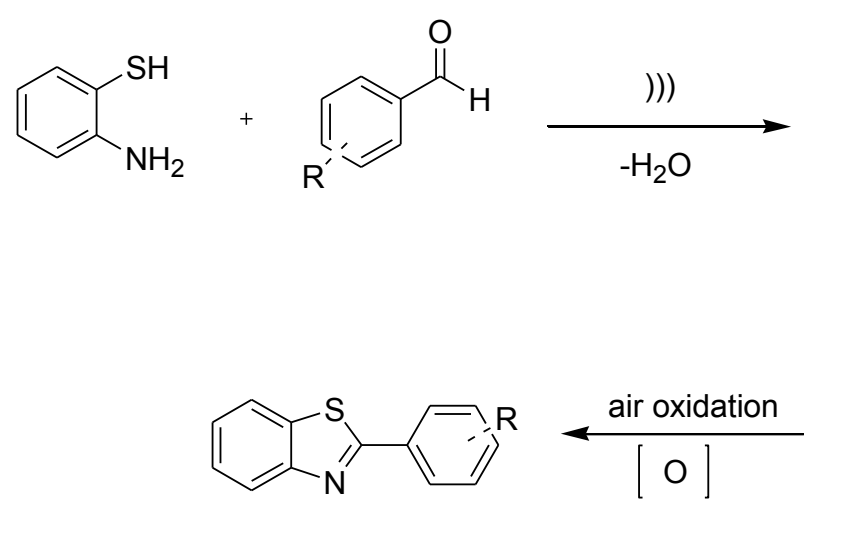

(II)

Scheme 2. A plausible mechanism for the synthesis of benzothiazole derivatives under ultrasound probe irradiation

\section{Conclusion}

In conclusion, we have demonstrated a simple and efficient protocol for the synthesis of benzothiazole derivatives under ultrasound probe irradiation. The major advantages of this technique include short reaction time, solvent- and catalyst-free reaction condition and the final products were obtained in moderate to good yields. These traits have rendered this method as an alternative way for synthesizing benzothiazole derivatives. In the future, the use of ultrasound probe irradiation under solvent- and catalyst-free condition to synthesize useful bioactive heterocyclic compounds will be further explored in our laboratory.

\section{Acknowledgement}

The author would like to acknowledge the financial support from Ministry of Higher Education Malaysia (RAGS Vot No. 57081) and Universiti Malaysia Terengganu.

1. Rezki, N. (2016). A green ultrasound synthesis, characterization and antibacterial evaluation of 1,4disubstituted 1,2,3-triazoles tethering bioactive benzothiazole nucleus. Molecules, 21: 1-13.

2. Gagoria, J., Verma, P. K. and Khatkar, A. (2015). Anticonvulsant and neurological profile of benzothiazoles: a mini-review. Central Nervous System Agents in Medicinal Chemistry, 15(1): 11 - 16.

3. Mohamed, L. W., Taher, A. T., Rady, G. S., Ali, M. M. and Mahmoud, A. E. (2017). Synthesis and cytotoxic activity of certain benzothiazole derivatives against human MCF-7 cancer cell line. Chemical Biology \& Drug Design, 89(4): 566 - 576.

4. Herrera Cano, N., Ballari, M. S., Lopez, A. G. and Santiago, A. N. (2015). New synthesis and biological evaluation of benzothiazole derivates as antifungal agents. Journal of Agriculture Food Chemistry, 63(14): $3681-3686$.

5. Shaik, T. B., Hussaini, S. M., Nayak, V. L., Sucharitha, M. L., Malik, M. S. and Kamal, A. (2017). Rational design and synthesis of 2-anilinopyridinyl-benzothiazole Schiff bases as antimitotic agents. Bioorganic \& Medicinal Chemistry Letters, 27(11): 2549 - 2558.

6. Gabr, M. T., Ei-Gohary, N. S, Ei-Bendar, E. R. and El-Kerdawy M. M. (2015). New series of benzotiazole and pyrimido[2,1-b]benzothiazole derivatives: Synthesis, antitumor activity, EGFR cyrosine kinase inhibitory activity and molecular modeling studies. Medicinal Chemistry Research, 24(2): 860 - 878.

7. Hatfield, S. M., Hartley, L. W. and Schmidtke, J. R. (1982). The immunomodulatory action of frentizole, a novel immunosuppressive agent. Immunopharmacology, 5(2): 169 - 179.

8. Drance, S. M. (1960). Ethoxzolamide (cardrase) in the management of chronic simple glaucoma. Archives Ophthalmology, 64: 433 - 437.

9. Doble, A. (1996). The pharmacology and mechanism of action of riluzole. Neurology, 47: 233 - 241. 
10. Chhabra, M., Sinha, S., Barnerjee, S. and Paira, P. (2016). An efficient green synthesis of 2-arylbenzothaizole analogues as potent antibacterial and anticancer agents. Bioorganic \& Medicinal Chemistry Letters, 26(1): 213 $-217$.

11. Chun, S., Yang, S. and Chung, Y. K. (2017). Synthesis of benzothiazoles from 2-aminobenzenethiols in the presence of a reusable polythiazolium precatalyst under atmospheric pressure of carbon dioxide. Tetrahedron, 73(25): $3438-3442$.

12. Ziarati, A., Sobhani-Nasab, A., Rahimi-Nasrabadi, M., Ganjali, M. R. and Badiei, A. (2017). Sonication method synergism with rare earth based nanocatalyst: preparation of $\mathrm{NiFe} 2-\mathrm{xEuxO} 4$ nanostructures and its catalytic applications for the synthesis of benzimidazoles, benzoxazoles, and benzothiazoles under ultrasonic irradiation. Journal of Rare Earths, 35(4): 374 - 381.

13. Waseem, M. A., Shireen, Srivastava, A., Srivastava, A., Rahila, and Siddiqui, I. R. (2015). Water and ionic liquid synergy: A novel approach for the synthesis of benzothiazole-2(3H)-one. Journal of Saudi Chemical Society, 19(3): $334-339$.

14. Chen, G.-F., Jia, H.-M., Zhang, L.-Y., Chen, B.-H. and Li, J.-T. (2013). An efficient synthesis of 2-substituted benzothiazoles in the presence of $\mathrm{FeCl} 3 /$ Montmorillonitrile $\mathrm{K}-10$ under ultrasound irradiation. Ultrasonics Sonochemistry, 20(2): $627-632$.

15. Li, J. T., Yin, Y., Li, L. and Sun, M. X. (2010). A convenient and efficient protocol for the synthesis of 5-aryl1,3-diphenylpyrazole catalyzed by hydrochloric acid under ultrasound irradiation. Ultrasonics Sonochemistry, 17(1): $11-30$.

16. Tan, S. H., Chuah, T. S. and Chia, P. W. (2016). An improved protocol on the synthesis of Thiazolo[3,2-a] pyrimidine using ultrasound probe irradiation . Journal of Korean Chemical Society, 60(4): $245-250$.

17. Heravi, M. R. P., Vessally, E. and Behbehani, G. R. R. (2014). An efficient green MCR protocol for the synthesis of 2,4,5-trisubstituted imidazoles by Selectfluor ${ }^{\mathrm{TM}}$ under ultrasound irradiation. Comptes Rendus Chimie, 17(2): $146-150$.

18. Nasrollahzadeh, M., Ehsani, A. and Rostami-Vartouni, A. (2014). Ultrasound-promoted green approach for the synthesis of sulfonamides using natural, stable and reusable Natrolite nanozeolite catalyst at room temperature. Ultrasonics Sonochemistry, 21(1): 275 - 282.

19. Li, J.-T., Wang, S.-X., Chen, G.-F. and Li, T.-S. (2005). Some applications of ultrasound irradiation in organic synthesis. Current Organic Synthesis, 2(3): 415 - 436.

20. Frizzo, C.P., Scapin, E., Marzari, M.R., München, T.S., Zanatta, N., Bonacorso, H.G., Buriol, L. and Martins, M.A. (2014). Ultrasound irradiation promotes the synthesis of new 1,2,4-triazolo [1,5-a]pyrimidine. Ultrasonics Sonochemistry, 21(3): 958 - 962.

21. Pardeshi, S. D., Sonar, J. P., Pawar, S. S., Dekhane, D., Gupta, S., Zine, A. M. and Thore, S. N. (2014). Sonicated assisted synthesis of benaimidazoles, benzoazoles and benzothiazoles in aqueous media. Journal of Chilean Chemical Society, 59(1): 2235 - 2340.

22. Gao, Y., Song, Q., Cheng, G. and Cui, X. (2014). KI-catalyzed arylation of benzothiazoles from the coupling of aryl aldehydes with benzothiazoles in neat water. Organic \& Biomolecular Chemistry, 12(7), $1044-1047$.

23. Banyopadhyay, P., Sathe, M., Prasad, G. K., Sharma, P. and Kaushik, M. P. (2011). Mesoporous mixed oxide nanocrystal: Efficient and recyclable heterogeneous catalyst for the synthesis of 1, 2-disubstituted benzimidazoles and 2-substituted benzothiazoles. Journal of Molecular Catalysis A: Chemical, 341(1): 77 - 82. 